\title{
REPORT OF THE WORKING GROUP ON FISHERY INTERACTIONS
}

Paulo H. Ott, Eduardo R. Secchi, Ignacio B. Moreno, Daniel Danilewicz, Enrique A. Crespo, Pablo Bordino, Renata Ramos, Ana Paula Di Beneditto, Carolina Bertozzi, Ricardo Bastida, Regina Zanelatto, Jorge Perez and Paul G. Kinas

Mortality of franciscana in fishing operations has been observed for almost sixty years. Reports on by-catch in shark gillnet fisheries off Uruguay date back to the early forties (Van Erp, 1969). Although gillneting in Argentina and southern Brazil also emerged in the forties as a consequence of Second World War demands for cheap protein and vitamins (De Buen, 1950, 1952; Popovici and Angelescu, 1954; Crespo et al., 1994; Haimovici et al., 1997), no record of by-catch exists for those areas. Gillnet fisheries for bottomdwelling fish became the major conservation concern for franciscana in both countries only in the eighties. Nowadays, by-catch has been reported from all main fishing villages along most of the species geographical distribution (e.g. Corcuera, 1994; Crespo et al., 1994; Pinedo, 1994a; Siciliano, 1994; Praderi, 1997; Secchi et al., 1997; Zanelatto, 1997; Di Beneditto et al., 1998; Ott, 1998). Gillnet fishing characteristics are summarized in Table 1. By-catch estimates for each of the proposed Franciscana Management Areas (FMAs) (Secchi et al., in press) are shown in Figure 1. Uruguay: Franciscana by-catch exists since the beginning of the gillnet fishery for sharks off Punta del Diabo (Van Erp, 1969). As early as the late sixties, annual by-catch may have reached 1,500 to 2,000 animals (Brownell and Ness, 1970; Pilleri, 1971). Results of the first systematic survey indicated a by-catch of at least 536 dolphins between 1971 and 1973 (Brownell and Praderi, 1974; Brownell, 1975). A mean annual by-catch of 279 franciscanas was reported for the following four years (Praderi 1985). Praderi (1984) and Crespo et al. (1986) also estimated the annual by-catch of franciscanas and presented levels of Catch Per Unit of Effort (CPUE) based on an extensive monitoring program of the fisheries between 1974 and 1983. A review paper on incidental mortality of the species in Uruguayan waters showed that at least 3,683 dolphins were killed in the region between 1974 and 1994 (Praderi, 1997). Annual estimates ranged between 66 and 418 dolphins caught in 1994 and 1974, respectively. In general, nets were set in water depths ranging from 6 to $30 \mathrm{~m}$, but most of the by-catch occurred in water from 10 to $20 \mathrm{~m}$ deep (Praderi, 1997).

Franciscana by-catch occurs in gillnets with stretched mesh sizes varying from 10 to $34 \mathrm{~cm}$. However, nets with the largest mesh size, targeting sharks (e.g. Carcharhinus spp, Carcharias platensis and Galeorhinus galeus), were responsible for about 70 to $90 \%$ of the captures (e.g. Praderi, 1997). During the last decades the stocks of targeted sharks have declined to an extent that the fisheries became unprofitable. Consequently, the fishing effort with the larger mesh sizes (i.e. $32-34 \mathrm{~cm}$ ) dropped from almost $100 \%$ in the sixties and seventies to only $20 \%$ in the mid nineties. Most of the fishers who traditionally used large boats with large mesh-sized nets to catch sharks are currently using smaller boats with small mesh-sized nets and now target bonny fishes (e.g. Sciaenidae fishes). Some are trawling for shellfish (Adelomelon brasiliana) (Praderi, 1997). These changes in the Uruguayan coastal fishery may allow franciscana to recover from the by-catch experienced in the past (Praderi, 1997). However, an uncontrolled increase of fishing effort using small mesh-sized nets for coastal bonny fishes and an intense by-catch of franscicana in adjacent areas of southern Brazil (see below) could compromise this recovery process.

Argentina: Perez-Macri and Crespo (1989) presented the first mortality estimates and CPUE for franciscana in Argentine waters. This study surveyed several fishing communities between 1984 and 1986 and estimated an annual mortality of at least 340-350 animals. Corcuera (1994), Corcuera et al. (1994) and Crespo et al. (1994) provided further information concerning franciscana and gillnet interactions along the Argentine coast, especially for the fishing communities placed along the Buenos Aires Province coast. The most complete information available comes from Necochea and Claromecó, where fisheries have been monitored since 1984 and 1988, respectively. The CPUE of franciscana has decreased considerably during the last years in Necochea, which holds one of the largest gillnet fishing fleet in Argentina. Such a decrease is mainly due to movements of the fleet to fishing grounds further offshore (Corcuera et al., 1994). Nowadays, most of the franciscana by-catch in Argentine waters occurs in fisheries carried out from small fishing camps in the Buenos Aires Province. Thus, the coastal habitat of franciscana makes it vulnerable to by-catch in small scale inshore gillnets (Corcuera, 1994; Cappozzo et al., 2000). Data over seven years, from mid 80 's and early 90 's, suggested an average annual bycatch of 237 (95\% CI: 208 to 269) franciscanas in southern Buenos Aires Province (Corcuera, 1994; Corcuera et al., 1994). Fishing villages of the northern Buenos Aires Province were monitored in 1997 and 1998 and annual by-catch in this area was estimated to be 228 (95\% CI: 200 to 260) animals (Corcuera et al., 2000). Estimates of by-catch for the same region from 1999 suggested a mean annual by-catch of 209 (95\% CI: 145 to 298) franciscanas (Cappozzo et al., 2000). The overall mortality of the species in the entire Buenos Aires Province seems to be around 450 to 500 dolphins/year (Cappozzo et al., 2000; Corcuera et al., 2000). It is important to note that research carried out onboard artisanal fishing boats off Cabo San Antonio resulted in much higher annual by-catch (17 dolphins per boat) than estimates obtained from interviews ( 10 dolphins per boat) (Bordino et al., 2000). Therefore, since most of the available data on by-catch in Argentine waters (e.g. Corcuera, 1994; Corcuera et al., 1994; Cappozzo et al., 2000) were obtained from interviews, it is likely that the total annual by-catch for this area is considerably underestimated.

A variety of fisheries operate along the Buenos Aires Province coast, depending on season and target species. However, most of the captures of franciscana occur in water shallower than $20 \mathrm{~m}$ deep in gillnets set for croaker (Sciaenidae species) and sharks (Galeorhinus galeus, Mustelus spp, Eugomphodus taurus, Squatina argentina) (Corcuera et al., 1994; Crespo et al., 1994). In Necochea, gillnets catching most of the franciscana are set at the bottom and have stretched mesh sizes from 18 to $28 \mathrm{~cm}$. Off Claromecó, franciscana by-catch also occurs in gillnets with stretched mesh sizes from 7 to 36cm (Corcuera, 1994; Corcuera et al., 1994). 
Table 1. Summary of incidental mortality of franciscana and the involved fisheries in the western South Atlantic.

\begin{tabular}{|c|c|c|c|c|c|}
\hline Locality & $\begin{array}{l}\text { Geographic } \\
\text { Sector* }\end{array}$ & $\begin{array}{l}\text { Annual } \\
\text { Mortality }\end{array}$ & $\begin{array}{c}\text { General Characteristic } \\
\text { of the Fisheries }\end{array}$ & Data Source & Reference \\
\hline $\begin{array}{l}\text { Regência and } \\
\text { Povoação, ES/Brasil } \\
\text { Latitude: } \\
19^{\circ} 38^{\prime} \mathrm{S}\end{array}$ & 2 & $\begin{array}{l}\text { Min.: } 5 \\
\text { Ave.: - } \\
\text { Max.: } 10\end{array}$ & $\begin{array}{l}\text { Fleet: } 12 \text { small boats } \\
\text { Power engines: - } \\
\text { Gear: gillnets } \\
\text { Main target species: - } \\
\text { Mesh size: - } \\
\text { Net width: - } \\
\text { Net length: - } \\
\text { Depth:- } \\
\text { Distance from the coast: } 1 \text { nautical mile } \\
\text { offshore } \\
\text { Fishing season: - } \\
\text { CPUE: - } \\
\text { Dolphin use: blubber as bait for lobster trap } \\
\text { and muscle for human consumption. }\end{array}$ & $\begin{array}{l}\text { Occasional } \\
\text { interview } \\
(1987 \text { and } \\
1989) \text {. }\end{array}$ & $\begin{array}{l}\text { Siciliano et } \\
\text { al., 1994; } \\
\text { Ramos et al., } \\
1994 .\end{array}$ \\
\hline $\begin{array}{l}\text { Atafona, RJ/Brasil } \\
\text { Latitude: } \\
21^{\circ} 37^{\prime} \mathrm{S}\end{array}$ & 3 & $\begin{array}{l}\text { Min.: } 8 \\
\text { Ave.: } 15 \\
\text { Max.: } 22\end{array}$ & $\begin{array}{l}\text { Fleet: } 140 \text { boats ( } 7-12 \mathrm{~m} \text { long) ( } 45 \% \text { use } \\
\text { gillnets). } \\
\text { Power engines: } 15-60 \mathrm{Hp} \\
\text { Gear: surface and bottom gillnets } \\
\text { Main target species: sciaenids and sharks } \\
\text { Mesh size: } 14 \mathrm{~cm} \\
\text { Net height: } 5.6 \mathrm{~m} \\
\text { Net length: up to } 2,400 \mathrm{~m} \\
\text { Depth: } 6-70 \mathrm{~m} \\
\text { Distance from the coast: up to } 60 \text { nautical } \\
\text { miles offshore } \\
\text { Fishing season: year-round } \\
\text { CPUE: - } \\
\text { Dolphin use: blubber as shark bait in longline } \\
\text { fishery }\end{array}$ & $\begin{array}{l}12 \text { years } \\
\text { (1987-1999) } \\
\text { fleet } \\
\text { monitoring } \\
\text { program } \\
(45 \% \text { of the } \\
\text { fleet). }\end{array}$ & $\begin{array}{l}\text { Di Beneditto } \\
\text { et al., 1998; } \\
\text { Di Beneditto } \\
\text { and Ramos, } \\
2000 .\end{array}$ \\
\hline $\begin{array}{l}\text { Bertioga to Peruíbe, } \\
\text { SP/Brasil } \\
\text { Latitude: } \\
23^{\circ} 59^{\prime} \mathrm{S}-24^{\circ} 20^{\prime} \mathrm{S}\end{array}$ & 4 and 5 & $\begin{array}{l}\text { Est. a: } \\
\text { Min.: } 22 \\
\text { Ave.: - } \\
\text { Max.: - } \\
\text { Est. b: } \\
\text { Min.: } 14 \\
\text { Ave.: - } \\
\text { Max.: - }\end{array}$ & $\begin{array}{l}\text { Fleet: } 6 \text { small boats (6-8m long) } \\
\text { Power engines: } 18-40 \mathrm{Hp} \\
\text { Gear: surface and bottom gillnets } \\
\text { Main target species: sciaenids, sharks } \\
\text { Mesh size: } 7-16 \mathrm{~cm} \\
\text { Net height: } 1.6-3.3 \mathrm{~m} \text { (bottom gillnets); } 7.4- \\
10 \mathrm{~m} \text { (surface gillnets) } \\
\text { Net length: } 120-1,800 \mathrm{~m} \\
\text { Depth: up to } 25 \mathrm{~m} \\
\text { Distance from the coast: - } \\
\text { Fishing season: year-round } \\
\text { CPUE: } 0.0020 \text { franciscana } \times\left(1,000 \mathrm{~m}^{2} \text { of net } \mathrm{x}\right. \\
\text { day) } \\
\text { Dolphin use: no records }\end{array}$ & $\begin{array}{l}\text { a) } 2 \text { years } \\
(1998-2000) \\
\text { survey of } \\
\text { stranded } \\
\text { cetaceans. } \\
\text { b) } 2 \text { years } \\
\text { (1998-2000) } \\
\text { fleet } \\
\text { monitoring } \\
\text { program } \\
\text { (100\% of the } \\
\text { fleet). } \\
\text { Interview and } \\
\text { onboard } \\
\text { surveys. }\end{array}$ & $\begin{array}{l}\text { a) Vicente } e t \\
\text { al., } 2000 . \\
\text { b) Bertozzi } \\
\text { and Zerbini, } \\
2000 .\end{array}$ \\
\hline
\end{tabular}

continued... 
Table 1. Summary of incidental mortality of franciscana and the involved fisheries in the western South Atlantic.

... continued

\begin{tabular}{|c|c|c|c|c|c|}
\hline Locality & $\begin{array}{l}\text { Geographic } \\
\text { Sector* }\end{array}$ & $\begin{array}{l}\text { Annual } \\
\text { Mortality }\end{array}$ & $\begin{array}{c}\text { General Characteristic } \\
\text { of the Fisheries }\end{array}$ & Data Source & Reference \\
\hline $\begin{array}{l}\text { Cananéia, SP/Brasil } \\
\text { Latitude: } \\
25^{\circ} 00^{\prime} \mathrm{S}\end{array}$ & 5 & $\begin{array}{l}\text { Est. a: } \\
\text { Min.: } 9 \\
\text { Ave.: - } \\
\text { Max.: - } \\
\text { Est. b: } \\
\text { Min.: } 11 \\
\text { Ave.: - } \\
\text { Max.: } 330\end{array}$ & $\begin{array}{l}\text { Fleet: } 30 \text { boats ( } 18 \mathrm{~m} \text { long) } \\
\text { Power engine: - } \\
\text { Gear: surface and bottom gillnets } \\
\text { Main target species: sciaenids and sharks } \\
\text { Mesh size: } 7-13 \mathrm{~cm} \\
\text { Net height: } 5-10 \mathrm{~m} \\
\text { Net length: up to } 6,000 \mathrm{~m} \text { (bottom gillnets); up } \\
\text { to } 2,000 \mathrm{~m} \text { (surface gillnets) } \\
\text { Depth: - } \\
\text { Distance from the coast: } 10-40 \text { nautical miles } \\
\text { offshore } \\
\text { Fishing season: year around (bottom gillnets), } \\
\text { May-July (surface gillnets) } \\
\text { CPUE: - } \\
\text { Dolphin use: no records }\end{array}$ & $\begin{array}{l}\text { a) } 2 \text { years } \\
(1986-1988) \\
\text { survey of } \\
\text { stranded } \\
\text { cetaceans. } \\
\text { b) } 2 \text { years } \\
\text { (1998-2000) } \\
\text { fleet } \\
\text { monitoring } \\
\text { program } \\
\text { (3\% of the } \\
\text { fleet, } n=30) \text {. } \\
\text { Interview. }\end{array}$ & $\begin{array}{l}\text { a) } \\
\text { Schmiegelow, } \\
1990 \\
\text { b) Rosas et } \\
\text { al., 2000a. }\end{array}$ \\
\hline $\begin{array}{l}\text { Pontal do Sul and } \\
\text { Matinhos, PR/Brasil } \\
\text { Latitude: } \\
25^{\circ} 18^{\prime} \mathrm{S}-25^{\circ} 58^{\prime} \mathrm{S}\end{array}$ & 6 & $\begin{array}{l}\text { Est. a: } \\
\text { Min.: } 5 \\
\text { Ave.: - } \\
\text { Max.: - } \\
\text { Est. b: } \\
\text { Min.: } 10 \\
\text { Ave.: - } \\
\text { Max.: } 25\end{array}$ & $\begin{array}{l}\text { Fleet: small boats ( } 7-10 \mathrm{~m} \text { long) } \\
\text { Power engine: } 11-36 \mathrm{Hp} \\
\text { Gear: surface and bottom gillnets } \\
\text { Main target species: sciaenids, sharks, mullets, } \\
\text { flounders } \\
\text { Mesh size: } 6-22 \mathrm{~cm} \\
\text { Net height: } 2-5 \mathrm{~m} \text { (bottom gillnets); } 8-12 \mathrm{~m} \\
\text { (surface gillnets) } \\
\text { Net length: } 500-1,200 \mathrm{~m} \\
\text { Depth: up to } 30 \mathrm{~m} \\
\text { Distance from the coast: up to } 5 \text { nautical miles } \\
\text { offshore } \\
\text { Fishing season: year around } \\
\text { CPUE: - } \\
\text { Dolphin use: eventually human consume }\end{array}$ & $\begin{array}{l}\text { a) } 7 \text { years } \\
\text { (1991-1997) } \\
\text { survey of } \\
\text { stranded } \\
\text { cetaceans. } \\
\text { b) } 2 \text { years } \\
\text { (1998-2000) } \\
\text { fleet } \\
\text { monitoring } \\
\text { program. } \\
\text { Interview. }\end{array}$ & $\begin{array}{l}\text { a) Zanellato, } \\
\text { 1997; } \\
\text { Rosas et al., } \\
2000 \mathrm{~b} . \\
\text { b) Rosas et } \\
\text { al., 2000a. }\end{array}$ \\
\hline $\begin{array}{l}\text { Farol de Santa Marta, } \\
\text { SC/BR } \\
\text { Latitude: } \\
28^{\circ} 29^{\prime} S\end{array}$ & 7 and 8 & $\begin{array}{l}\text { Est. a: } \\
20-30 \\
\text { Est. b: } \\
120\end{array}$ & $\begin{array}{l}\text { Fleet: } 60-70 \text { small boats } \\
\text { Power engine: - } \\
\text { Gear: gillnet } \\
\text { Main target species: sciaenids, gadids and } \\
\text { sharks } \\
\text { Mesh size: } 10-40 \mathrm{~cm} \\
\text { Net height: } 3 \mathrm{~m} \\
\text { Net length: } 1,500-2,225 \mathrm{~m} \\
\text { Depth: - } \\
\text { Distance from the coast: } \sim 8-10 \text { nautical miles } \\
\text { offshore } \\
\text { Fishing season: year-round } \\
\text { CPUE: - } \\
\text { Dolphin use: - }\end{array}$ & $\begin{array}{l}\text { a) Occasional } \\
\text { Interview. } \\
\text { b) } 1 \text { year } \\
\text { (1994-1995) } \\
\text { fleet } \\
\text { monitoring } \\
\text { program } \\
\text { (25\% of the } \\
\text { fleet). } \\
\text { Interview and } \\
\text { onboard data. }\end{array}$ & $\begin{array}{l}\text { a) Pinedo, } \\
1994 \mathrm{~b} \\
\text { b) Cremer et } \\
\text { al., } 1995\end{array}$ \\
\hline
\end{tabular}


Table 1. Summary of incidental mortality of franciscana and the involved fisheries in the western South Atlantic.

... continued

\begin{tabular}{|c|c|c|c|c|c|}
\hline Locality & $\begin{array}{l}\text { Geographic } \\
\text { Sector* }\end{array}$ & $\begin{array}{l}\text { Annual } \\
\text { Mortality }\end{array}$ & $\begin{array}{c}\text { General Characteristic } \\
\text { of the Fisheries }\end{array}$ & Data Source & Reference \\
\hline $\begin{array}{l}\text { Torres and } \\
\text { Tramandai/Imbe, } \\
\text { RS/BR } \\
\text { Latitude: } \\
29^{\circ} 15^{\prime} \text { S- } 29^{\circ} 58^{\prime} \text { 'S }\end{array}$ & 8 and 9 & $\begin{array}{l}\text { Est. a: } \\
\text { Min.: } 300 \\
\text { Ave.: } 425 \\
\text { Max.: } 550 \\
\text { Est. b: } \\
46\end{array}$ & $\begin{array}{l}\text { Fleet: } 30 \text { boats (10-18m long) } \\
\text { Power engine: } 90-160 \mathrm{Hp} \\
\text { Gear: bottom and surface gillnets } \\
\text { Main target species: sciaenids, gadids and sharks } \\
\text { Mesh size: } 9-38 \mathrm{~cm} \\
\text { Net height: } 3 \mathrm{~m} \text { (bottom gillnets); } 8-15 \mathrm{~m} \\
\text { (surface gillnets) } \\
\text { Net lengt: up to } 4,500 \mathrm{~m} \text { (bottom gillnets); } 300 \text { - } \\
1,500 \mathrm{~m} \text { (surface gillnets) } \\
\text { Depth:10-40m } \\
\text { Distance from the coast: up to } 20 \text { nautical } \\
\text { miles offshore } \\
\text { Fishing season: year-round } \\
\text { CPUE: } 0.0540 \text { to } 0.0880 \text { franciscanas x (1,000 } \\
\text { m of net x day) } \\
\text { Dolphin use: no records at the present } \\
\text { (occasionally in the past) }\end{array}$ & $\begin{array}{l}\text { a) } 5 \text { years } \\
\text { (1992-1997) } \\
\text { fleet } \\
\text { monitoring } \\
\text { program } \\
\text { ( } 40 \% \text { of the } \\
\text { fleet). } \\
\text { Interview and } \\
\text { onboard } \\
\text { surveys. } \\
\text { b) } 10 \text { years } \\
\text { (1991-2000) } \\
\text { survey of } \\
\text { stranded } \\
\text { cetaceans. }\end{array}$ & $\begin{array}{l}\text { a) Ott, 1998; } \\
\text { Ott et al., } \\
2000 \mathrm{a} . \\
\text { b) Moreno et } \\
\text { al., } 2001 .\end{array}$ \\
\hline $\begin{array}{l}\text { Rio Grande, } \\
\text { RS/Brasil } \\
\text { Latitude: } \\
32^{\circ} 05^{\prime} \mathrm{S}\end{array}$ & 10 & $\begin{array}{l}\text { Est. a: } 84 \\
\text { Est. b: } \\
\text { Min.: } 196 \\
\text { Ave.: } 461 \\
\text { Max.: } 518 \\
\text { Est. c: } \\
810\end{array}$ & $\begin{array}{l}\text { Fleet: } 140-150 \text { boats }(12-16 \mathrm{~m} \text { long) } \\
\text { Power engine: } 90-120 \mathrm{Hp} \\
\text { Gear: gillnets (passive and active) } \\
\text { Main target species: sciaenid and pomatomids } \\
\text { Mesh size: } 9-16 \mathrm{~cm} \\
\text { Net height: } 2-4 \text { (passive nets) and } 6-14 \mathrm{~m} \text { (active) } \\
\text { Net length: } 3,000-11,000 \mathrm{~m} \text { (passive); } 800- \\
4,000 \mathrm{~m} \text { (active) } \\
\text { Depth: up to } 35 \mathrm{~m} \\
\text { Distance from the coast: up to } 30 \text { miles } \\
\text { offshore } \\
\text { Fishing season: year round } \\
\text { CPUE: } 0.0066 \text { franciscanas x ( } 1,000 \mathrm{~m} \text { of net x } \\
\text { day) (passive); } \\
0.0038 \text { franciscanas x (operation x day) } \\
\text { Dolphin use: few fishers use the oil to } \\
\text { waterproof boats and the meat is sometimes } \\
\text { used for feeding dogs and even rarely for } \\
\text { human consumption. }\end{array}$ & $\begin{array}{l}\text { a) } 11 \text { years } \\
\text { (1976-1987) } \\
\text { survey of } \\
\text { stranded } \\
\text { cetaceans. } \\
\text { b) } 1 \text { year } \\
\text { (1994) fleet } \\
\text { monitoring } \\
\text { program } \\
\text { (25\% of the } \\
\text { fleet). } \\
\text { Interview. } \\
\text { c) } 1 \text { year } \\
\text { (2000) fleet } \\
\text { monitoring } \\
\text { program ( } 7 \% \\
\text { of the fleet). } \\
\text { Interview. }\end{array}$ & $\begin{array}{l}\text { a) Pinedo, } \\
\text { 1994a. } \\
\text { b) Secchi et } \\
\text { al., 1997; } \\
\text { Kinas and } \\
\text { Secchi, } \\
\text { 1998, } 1999 . \\
\text { c) Secchi et } \\
\text { al., unpubl. } \\
\text { data. }\end{array}$ \\
\hline $\begin{array}{l}\text { Uruguay } \\
\text { Latitude: } \\
33^{\circ} 45^{\prime} \mathrm{S}-34^{\circ} 55^{\prime} \mathrm{S}\end{array}$ & 11 and 12 & $\begin{array}{l}\text { Min.: } 66 \\
\text { Ave.: } 184 \\
\text { Max.: } 418\end{array}$ & $\begin{array}{l}\text { Fleet: } 20 \text { boats in the } 70 \text { 's, } 3 \text { boats in the mid } 1990 \text { 's, } \\
\text { fishing only off Punta del Diablo. (6-8m long) } \\
\text { Power engine: up to } 80 \mathrm{Hp} \\
\text { Gear: gillnets } \\
\text { Main target species: historically sharks, } \\
\text { currently sciaenids } \\
\text { Mesh size: } 10-12,20-22 \text { and } 32-34 \mathrm{~cm} \\
\text { Net height: } 3-5 \mathrm{~m} \\
\text { Net length: up to } 1,680 \mathrm{~m} \\
\text { Depth: } 6-30 \mathrm{~m} \\
\text { Distance from the coast: } 2-30 \text { nautical miles } \\
\text { offshore } \\
\text { Fishing season: mostly in summer } \\
\text { CPUE: } 0.0064 \text { franciscanas } x\left(1,000 \mathrm{~m} \text { of net x day) }{ }^{1}\right. \\
\text { Dolphin use: recent commercial use of } \\
\text { franciscana oil }\end{array}$ & $\begin{array}{l}20 \text { years } \\
\text { (1974-1994) } \\
\text { fleet } \\
\text { monitoring } \\
\text { program } \\
\text { (most of the } \\
\text { fleet). } \\
\text { Interviews. }\end{array}$ & $\begin{array}{l}\text { Praderi et al., } \\
1989 ; \\
\text { Praderi, } \\
1997\end{array}$ \\
\hline
\end{tabular}


Table 1. Summary of incidental mortality of franciscana and the involved fisheries in the western South Atlantic.

... continued

\begin{tabular}{|c|c|c|c|c|c|}
\hline Locality & $\begin{array}{l}\text { Geographic } \\
\text { Sector* }\end{array}$ & $\begin{array}{l}\text { Annual } \\
\text { Mortality }\end{array}$ & $\begin{array}{c}\text { General Characteristic } \\
\text { of the Fisheries }\end{array}$ & Data Source & Reference \\
\hline $\begin{array}{l}\text { North Buenos Aires } \\
\text { Province/Argentina } \\
\text { Latitude: } \\
35^{\circ} 00^{\prime}-38^{\circ} 08^{\prime} \mathrm{S}\end{array}$ & $\begin{array}{c}12,13 \text { and } \\
14\end{array}$ & $\begin{array}{l}\text { Est. a: } \\
\text { Min.: } 200 \\
\text { Ave.: } 228 \\
\text { Max.: } 260 \\
\text { Est. b } \\
\text { Min.: } 145 \\
\text { Ave.: } 209 \\
\text { Max.: } 298\end{array}$ & $\begin{array}{l}\text { Fleet: } 45 \text { boats ( } 5-12 \mathrm{~m} \text { long) } \\
\text { Power engine: - } \\
\text { Gear: gillnets } \\
\text { Main target species: sciaenids and sharks to a } \\
\text { less extent } \\
\text { Mesh size: } 10-30 \mathrm{~cm} \\
\text { Net height: } 3-5 \mathrm{~m} \\
\text { Net length: } 200 \text { to } 4,000 \mathrm{~m} \\
\text { Depth: up to } 25-30 \mathrm{~m} \\
\text { Distance from the coast: up to } 25-30 \text { nautical } \\
\text { miles } \\
\text { Fishing season: mostly in summer } \\
\text { CPUE: } 0.2161 \text { to } 0.4289 \text { franciscanas x (1,000 } \\
\text { m of net x day) } \\
\text { Dolphin use: human consume ("mushame") in } \\
\text { some areas }\end{array}$ & $\begin{array}{l}\text { a) } 1 \text { year } \\
\text { (1997-1998) } \\
\text { fleet } \\
\text { monitoring } \\
\text { program. } \\
\text { Interviews. } \\
\text { b) } 1 \text { year } \\
\text { (1999-2000) } \\
\text { fleet } \\
\text { monitoring } \\
\text { program. } \\
\text { Interview and } \\
\text { onboard } \\
\text { surveys. }\end{array}$ & $\begin{array}{l}\text { a) Corcuera } \\
\text { et al., } 2000 \\
\text { b) Capozzo et } \\
\text { al,. } 2000\end{array}$ \\
\hline $\begin{array}{l}\text { South Buenos Aires } \\
\text { Province/Argentina } \\
\text { Latitude: } \\
38^{\circ} 08^{\prime} \mathrm{S}-40^{\circ} 30^{\prime} \mathrm{S}\end{array}$ & $\begin{array}{c}14,15 \text { and } \\
16\end{array}$ & $\begin{array}{l}\text { Est. a: } \\
\text { Min.: } 208 \\
\text { Ave.: } 237 \\
\text { Max.: } 269 \\
\text { Est. b: } \\
\text { Min.: } 96 \\
\text { Ave.: } 135 \\
\text { Max.: } 189\end{array}$ & $\begin{array}{l}\text { Fleet: } 22 \text { boats using gillnets ( } 5-12 \mathrm{~m} \text { long), } 58 \\
\text { using shrimpers } \\
\text { Power engine: - } \\
\text { Gear: gillnets and shrimp trawling nets } \\
\text { Main target species: sciaenids and sharks to a less } \\
\text { extent (gillnets), Pleoticus sp. and Artemesia sp. } \\
\text { (shrimpers) } \\
\text { Mesh size: } 10-30 \mathrm{~cm} \text { for gillnets, } 2-6 \mathrm{~cm} \text { for } \\
\text { shrimpers } \\
\text { Net height: } 3-5 \mathrm{~m} \text { for gillnets } \\
\text { Net length: } 200 \text { to } 4,000 \mathrm{~m} \text { for gillnets } \\
\text { Depth: up to } 25-30 \mathrm{~m} \\
\text { Distance from the coast: up to } 25-30 \text { nautical } \\
\text { miles offshore } \\
\text { Fishing season: mostly in summer } \\
\text { CPUE (gillnets): } 0.0734 \text { franciscanas } \mathrm{x}(1,000 \\
\text { m of net x day) } \\
\text { High mortality also reported for shrimp } \\
\text { trawling nets } \\
\text { Dolphin use: - }\end{array}$ & $\begin{array}{l}\text { a) } 7 \text { years } \\
\text { (1988-1994) } \\
\text { fleet } \\
\text { monitoring } \\
\text { program. } \\
\text { Interview and } \\
\text { onboard } \\
\text { surveys. } \\
\text { b) } 1 \text { year } \\
\text { (1999-2000) } \\
\text { fleet } \\
\text { monitoring } \\
\text { program. } \\
\text { Interview and } \\
\text { onboard } \\
\text { surveys. }\end{array}$ & $\begin{array}{l}\text { a) Corcuera, } \\
\text { 1994; } \\
\text { Corcuera et } \\
\text { al., } 1994 . \\
\text { b) Capozzo et } \\
\text { al., } 2000 .\end{array}$ \\
\hline
\end{tabular}

References:

(Est.) estimation, (Min.) minimum, (Ave.) average, (Max) maximum.

* Geographic Sectors are shown in the Report of the Fourth Workshop (Secchi et al., in this volume) 


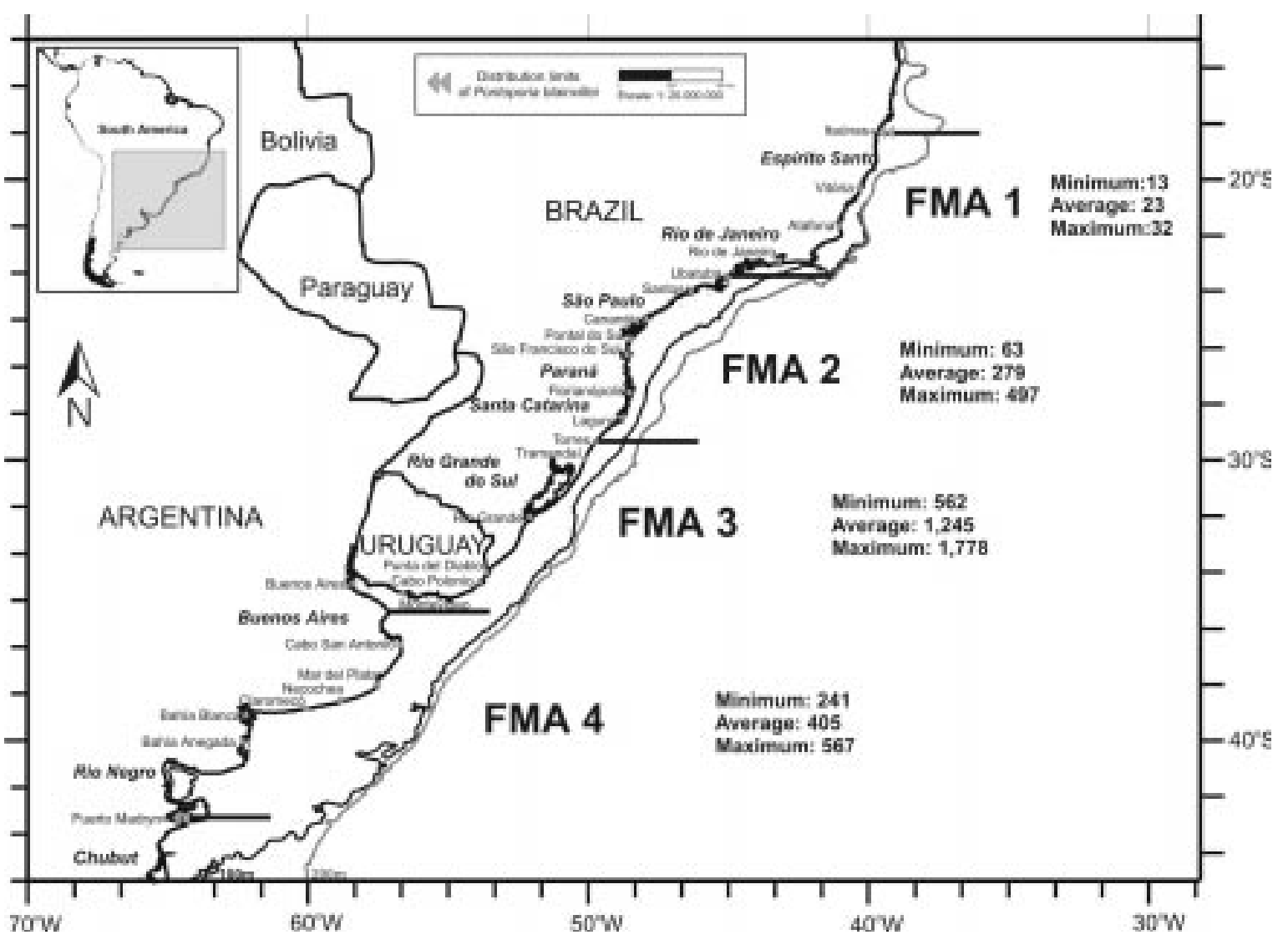

Figure 1. By-catch estimates for each of the proposed Franciscana Management Areas (FMAs).

Gillnet fishing effort has decreased in some important fishing ports (e.g. Necochea and Claromecó) due to the decline of some shark stocks (see Chiaramonte, 1998). Reduction in fishing effort has also occurred off Cabo San Antonio because of interactions with southern sea lions (Otaria flavescens), which damage the nets and the catches (Cappozzo et al., 2000). Although this decline of gillneting activities might reduce franciscana by-catch, shrimp trawling nets have recently been responsible for a high bycatch off Ingeniero White and Puerto Rosales, southern Buenos Aires Province (Cappozzo et al., 2000).

Coastal gillneting activities are highly seasonal, occurring only during spring in some areas and extending from spring to summer in others (Corcuera, 1994; Cappozzo et al., 2000). However, the annual level of franciscana by-catch seems to be high and should be evaluated according to the population size. Therefore, abundance estimates for franciscana off Argentina are a priority for the near future.

To date, no surveys to estimate by-catch in Rio Negro Province have been done. In the Province of Chubut no gillnet is used. Bottom trawling fisheries directed to hake, Merlucius hubbsi, predominate. However, the hake fishery occur further offshore beyond the franciscanas' habitat. Also dredge trawls are used to catch shellfish (e.g. Mytilus edulis and Chlamys tehuelchus). Although they occur in coastal waters, no franciscana catches have been reported in these fisheries (Crespo et al., 1994).

Brazil: The coastal gillnet fishery emerged in the forties and increased especially during the eighties. Vessels expanded in size and engines became more powerful, which allowed longer trips and the use of larger nets (Haimovici et al., 1997). A wide variety of vessels and fishing gears are employed according to the season and target species. However, active and passive gillnets targeting sciaenids (e.g. Micropogonias furnieri, Cynoscion spp, Menticirrhus spp), pomatomids (Pomatomus saltatrix) and sharks (e.g. Mustelus sp., Sphyrna spp, Rhizoprionodon sp.) predominate in coastal waters (see Table 1). The boats used in this fishery range in length from 6 to $18 \mathrm{~m}$ and normally operate from coastal to offshore (60 nautical miles) waters. Gillnets vary in length from 120 to 11,000m (e.g. Rio Grande), with stretched mesh sizes varying from 7 to $40 \mathrm{~cm}$. Most of the gillnets are set in waters $30 \mathrm{~m}$ deep, which corresponds to the preferred habitat of the franciscana (Praderi et al., 1989; Secchi and Ott, 2000). The fishery as well as captures of franciscanas occur throughout the year.

Although the gillnet fishery exist since the 40s, the first information regarding franciscana by-catch was published in the eighties (e.g. Pinedo, 1982, 1986; Praderi et al., 1989). However, this information was based exclusively on the number of animals with gillnet marks found dead on beaches in southern Brazil. According to Pinedo (1994a), 1,085 specimens were found along the Rio Grande do Sul coast between 1976 and 1987. Further information on franciscana strandings was also published for other areas 
along the Brazilian coast (e.g. Schmiegelow, 1990; Pinedo, 1994a; Vicente et al., 2000; Moreno et al., 2001). However, the first study of incidental mortality of franciscana dolphins based on monitoring of fishing operations was started in the late 80 's for a small village (Atafona) in Rio de Janeiro State, southeastern Brazil (Lodi and Capistrano, 1990). Since then, this fishing village has been systematically surveyed. From 1986 to 1999, a total of 181 franciscanas were incidentally caught in gillnets in this area, representing a mean annual mortality of $15 \pm 7$ dolphins (Di Beneditto et al., 1998; Di Beneditto and Ramos, 2000). Franciscana by-catch in fishing communities of the Rio Grande do SulState, southern Brazil, has also been systematically studied since the 90 's. The estimated annual mortality of franciscana for this area ranges from 496 to 1,360 dolphins (Moreno et al., 1997; Secchi et al., 1997; Ott, 1998; Kinas and Secchi, 1998, 1999; Secchi, 1999; Ott et al., 2000a). These are the highest levels of incidental kills of franciscana (Table 1). Removal rates relative to population size are high and possibly unsustainable on a long-term basis (Secchi, 1999; Kinas, 2000; Secchi and Kinas, 2000; Secchi et al., 2000; Secchi et al., 2001).

It is worthwhile to notice that these by-catch values, estimated from monitoring the gillnet fishing fleet in southern Brazil, are appreciably higher than data for the same region based on beached animals (e.g. Pinedo, 1994a; Moreno et al., 2001). This strongly suggests that data gathered from beach surveys should be view with caution when evaluating the impact of fisheries.

In recent years, many other studies concerning the franciscana and gillnet interactions have been carried out along the Brazilian coast. Although data from monitoring of fishing fleets are not available for many areas between Rio Grande do Sul and Rio de Janeiro States, some villages along the Santa Catarina, Paraná and São Paulo States coasts have been monitored recently. Preliminary by-catch estimates are available for some of them (e.g. Cremer et al., 1995; Bertozzi and Zerbini, 2000; Rosas et al., 2000a). Some of these data (e.g. Bertozzi and Zerbini, 2000) suggest that small fishing villages can impose a great impact on franciscana population, similar to the situation off the Argentine coast. On the coast of Paraná State, there are a few records of franciscana deaths in longlines (Zanellato, 1997), though this seems to be rare.

To summarize the information from fleet monitoring schemes, annual mortality of franciscana due to by-catch off the Brazilian coast ranges from 564 to 1,889 (Table 1). These results certainly represent an underestimation of the by-catch in Brazilian waters because many coastal fishing villages are either poorly or not surveyed at all. In addition, fishers in general tend to under-report by-catches. Therefore, increasing the monitoring effort of the gillnet fishery, including the small fishing camps, is urgently needed. Moreover, levels of franciscana mortality in longlining and trawling operations need to be investigated in order to obtain a more complete understanding of the threats fisheries pose to franciscana in Brazilian waters.

General characteristics of the bycatch of franciscana dolphins: The mortality of franciscana is incidental and there is no indication of direct exploitation of the species. The dolphins are typically found dead in gillnets when fishers retrieve their catch. Even though there are a few records of dolphins released alive from nets (e.g. Crespo et al. 1994; Bertozzi and Zerbini, 2000), in general there is little opportunity for live release of the dolphins. This is likely due to the long time that gillnets remain in the water. Soak time ranges typically from 8 to 24 hours.

Fishers normally discard by-caught dolphins offshore, although in some regions captured animals may be consumed or used otherwise. Blubber has been used as shark bait in longline fisheries in a fishing village in southeastern Brazil (Atafona), although this fishery is currently uncommon in that area (Di Beneditto and Ramos, 2000). Along the Paraná coast, there are records of franciscana meat being used for human consumption (Zanellato, 1997). In southern Brazil, fishers sometimes use oil obtained from franciscana carcasses to waterproof boats. In addition, meat may be used to feed dogs and rarely for human consumption (Secchi et al., 1997). Nevertheless, this is not a tradition in these communities and dolphins killed in gillnets are typically discarded at sea. In Uruguay, franciscana oil is recently being used commercially to treat horsehair (UNEP/CMS, 2000). In Argentine waters there is little utilisation of by-catch, although in a few areas (e.g. San Clement del Tuyú) sun dried and salted meat, locally known as "mushame", is consumed by Turkish, Jewish and Arabian members of the communities (Praderi et al., 1989). In several coastal communities in the Buenos Aires Province there are also popular references to the use of franciscana oil in the early 20th century, chiefly for domestic medical treatments and improvement of horse saddle leather (R. Bastida, pers. commn).

Fishers do not consider franciscana as a competitor for fish resources. Although the carcasses of an entangled dolphin can cause damage to nets during hauling, these damages are typically small, especially when compared to those caused by southern sea lions (Otaria flavescens) (e.g. Corcuera et al., 1994; Ott, 1998).

Most franciscanas are caught in gillnets in spring and summer in Uruguayan and Argentine waters and year around off Brazil (Table 1).

Although most of the captures involve one or two animals (e.g. Corcuera et al., 1994; Ott, 1998; Rosas et al., 2000a), up to nine dolphins were caught in a same net $(2,000 \mathrm{~m}$ long) off southern Brazil (Moreno et al., 1997). Both males and females are vulnerable to fishing operations, although the sex ratio of incidentally caught animals varies between regions (e.g. 1.61 males/female [n=47] in Buenos Aires Province, Argentina; 1.1 males/female [n=107] in Rio Grande, Brazil) (Corcuera, 1994; Secchi et al., 1997, respectively).

Similar to other small cetaceans, a large proportion of bycaught franciscanas are immature (e.g. Kasuya and Brownell, 1979; Crespo et al., 1986, Perez-Macri and Crespo, 1989; Corcuera et al., 1994; Ott et al., 2000b; Ramos et al., 2000). For example, in fishing communities of Argentina, Uruguay and Brazil, more than half of the caught specimens were less than 3 years old (Table 2). This bias towards higher catches of 
Table 2. Age structure of franciscana dolphins incidentally caught in gillnet fisheries.

\begin{tabular}{|c|c|c|c|c|c|c|c|}
\hline Locality & $\begin{array}{l}\text { Geographic } \\
\text { Sector* }\end{array}$ & Period & $\mathrm{n}$ & $\begin{array}{c}\text { Mode Age } \\
\text { (\% in } \\
\text { brackets) }\end{array}$ & $\begin{array}{c}\% \text { of } \\
<3 \text { years }\end{array}$ & $\begin{array}{c}\text { Maximum } \\
\text { Age }\end{array}$ & Reference \\
\hline Brazil (RJ) & 3 & $1989-98$ & 91 & $2(28.5)$ & 75.0 & 9 & Di Beneditto and Ramos, 2000 \\
\hline $\operatorname{Brazil}(\mathrm{RS})^{\mathrm{a}}$ & $8-10$ & 1976-80 & 97 & $1(23.7)$ & 42.3 & 16 & Pinedo, 1994b \\
\hline $\operatorname{Brazil}(\mathrm{RS})^{\mathrm{a}}$ & $8-10$ & $1982-86$ & 81 & $3(16.0)$ & 37,0 & 13 & Pinedo, 1994b \\
\hline Brazil (RS) & $8-10$ & 1992-97 & 147 & $1(34.7)$ & 64.0 & 11 & Ott et al., 2000b \\
\hline Uruguay $^{b}$ & $11-12$ & $1970-73$ & 218 & $1(46.8)$ & 73.9 & 16 & Kasuya and Brownell, 1979 \\
\hline Uruguay & $11-12$ & 1969-72 & 102 & $1(29.4)$ & 52.0 & 21 & Pinedo, 1994b \\
\hline Uruguay & $11-12$ & $1973-75$ & 108 & $1(38.0)$ & 63.9 & 14 & Pinedo, $1994 \mathrm{~b}$ \\
\hline Uruguay & $11-12$ & $1980-82$ & 34 & $1(55.9)$ & 70.6 & 19 & Pinedo, 1994b \\
\hline Uruguay & $11-12$ & $1980-81$ & 114 & $1(45.6)$ & 80.7 & 5 & Crespo et al., 1986 \\
\hline Argentina (BA) & $13-14$ & $1983-86$ & 22 & $\begin{array}{l}1(36.4)- \\
3(36.4)\end{array}$ & 50.0 & 4 & Perez-Macri and Crespo, 1989 \\
\hline Argentina (BA) & 14 & $1988-90$ & 42 & $\begin{array}{l}0(21.4) \text { - } \\
1(21.4)\end{array}$ & 57.1 & 8 & Corcuera et al., 1994 \\
\hline
\end{tabular}

References: $\left({ }^{a}\right)$ sample from stranded animals; $\left({ }^{b}\right)$ sample bias toward adult females for reproductive studies.

* Geographic Sectors are shown in the Final Report of the Fourth Workshop (in this volume); (n) sample size; (RJ) Rio de Janeiro; (RS) Rio Grande do Sul; (BA) Buenos Aires Province. Age estimated based on growth layer groups (modified from Ott et al., 2000b).

juveniles compared to adult individuals could reflect either the age structure of local populations or different behaviour of young animals, making them more vulnerable to incidental catches. Since we have no information on local age structures and age-related behavioural differences, it is not possible to determine the reason for this age bias in incidental catches. Nevertheless, potential effects of these captures on future recruitment rates of the population are a cause for concern, especially considering the low reproductive potential and short life span of the franciscana (Secchi, 1999; Danilewicz et al., 2000).

Conservation measures: Although gillnet fishing is recognized as the major threat to franciscana populations, few attempts have been made to reduce or eliminate the incidental capture of this species in gillnets. Until recently, only two management actions were proposed for some fishery communities: replacing gillnets with longlines (Corcuera et al., 1994) and seasonal area closures in southern Brazil (Secchi, 1999). Even though these measures may be effective, both may reduce fishers' income and would be difficult to implement. Therefore, new approaches are urgently needed.

Bordino et al. (2000) carried out an experiment using acoustic pingers to reduce by-catches of franciscana off Cabo San Antonio, Argentina. Although the pingers reduced the by-catches, they also increased the rate of attacks of southern sea lions on fish caught in the nets. Therefore, acoustic devices seem unsuitable as a longterm management option in this region. However, further pinger studies should be carried out in other areas. New approaches to gillnet modifications to minimise franciscana mortality should be encouraged. Nevertheless, evaluation of potential solutions must consider possible effects on the wider marine ecosystem in which they are to be employed. In addition, impacts on the social and cultural aspects of the local communities involved must also be taken into account.

\section{Recommendations}

The rate of by-catch of franciscana across its distribution urgently requires management measures to prevent the collapse of local populations or stocks. These measures need to be based on reliable and up-to-date information. Therefore, we recommend (see also the recommendation of the workshop):

- To estimate by-catch as accurately as possible using direct monitoring by independent onboard observers, wherever it is practical;

- To estimate CPUE using standardised and complete description of fishing effort, including its seasonal variability and fishing characteristics (e.g. type of nets, fishing area, size and power of boats);

- To identify areas and/or season of highest bycatch; and

- To model the effects of fishing by-catch on the potential rate of population increase by varying fishing effort and population parameters.

\section{References}

Bertozzi, C. and Zerbini, A. (2000) Capturas acidentais de franciscanas, Pontoporia blainvillei, na pesca artesanal de Praia Grande, São Paulo, Brasil. Technical Paper WP22 presented to the IV Workshop para a Coordenação da Pesquisa e Conservação da Franciscana, Pontoporia blainvillei, no Atlântico Sul Ocidental. 0509 November, Porto Alegre.

Bordino, P., Kraus, S., Albareda, D., Baldwin, K., Fazio, A. Palmeiro, A., Mendez, M., and Botta, S. (2000) Use of acoustic alarms to reduce the by-catch of franciscana, Pontoporia blainvillei, in gillnets. Technical Paper WP18 presented to the 
IV Workshop para a Coordenação da Pesquisa e Conservação da Franciscana, Pontoporia blainvillei, no Atlântico Sul Ocidental. 0509 November, Porto Alegre.

Brownell Jr., R.L. (1975) Progress report on the biology of the franciscana dolphin, Pontoporia blainvillei, in Uruguayan waters. Journal of Fishery Research Board of Canada 32: 1073-1078.

Brownell Jr., R.L. and Ness, R. (1970) Preliminary notes on the biology of the franciscana, Pontoporia blainvillei, (Cetacea: Platanistidae). Pages 23-28 in Proceedings of the Sixth Annual Conference on Biology and Sonar Diving Mammals - 1969. Stanford Res. Inst., Menlo Park.

Brownell Jr., R.L. and Praderi, R. (1974) Present research and conservation problems with the franciscana, Pontoporia blainvillei, in Uruguayan waters. Technical Report (ACMRR/MM/ SC/23). FAO Advisory Commitee on Marine Resources Research, 16-19 December 1974, La Jolla.

Buen, F. De (1950) El tiburón vitamínico de la costa uruguaya, Galeorhinus vitaminicus nov. sp. y algunas consideraciones generales sobre su biología. Publicación Científica S.O.Y.P., Montevideo 4: 153-162.

Buen, F. De (1952) El tiburón vitamínico. Revista de la Facultad de Ciencias Humanas de Montevideo 7: 87-116.

Cappozzo, L.H., Monzón, F., Perez, J.E., Albareda, D. and Corcuera, J. (2000) Mortalidad del defin franciscana, Pontoporia blainvillei, en la Provincia Buenos Aires. Technical Paper WP24 presented to the IV Workshop para a Coordenação da Pesquisa e Conservação da Franciscana, Pontoporia blainvillei, no Atlântico Sul Ocidental. 05-09 November, Porto Alegre.

Chiaramonte, G.E. (1998) Shark fisheries in Argentina. Marine and Freshwater Research 49: 601-610.

Corcuera, J. (1994) Mortality of Pontoporia blainvillei in Northern Buenos Aires Province: the threat of small fishing camps. Pages 291-294 in Perrin, W.F, Donovan, G.P. and Barlow, J. (Eds) Gillnets and cetaceans. International Whaling Commission (special issue 15), Cambrige.

Corcuera, J., Monzón, F., Cornejo, I, Perez, J., Beilis, A., Gingarelli, M., Albareda, D. and Arias, A. (2000) Mortalidad de Pontoporia blainvillei en el norte de la Provincia de Buenos Aires. Pages 7580 in UNEP/CMS (Eds) Report of the Third Workshop for Coordinated Research and Conservation of the Franciscana Dolphin (Pontoporia blainvillei) in the Southwestern Atlantic. UNEP/CMS, Bonn.

Corcuera, J., Monzón, F., Crespo, E.A., Aguilar, A. and Raga, J.A. (1994) Interactions between marine mammals and the coastal fisheries of Necochea and Claromecó (Buenos Aires, Argentina). Pages 283-290 in Perrin, W.F, Donovan, G.P. and Barlow, J. (Eds) Gillnets and cetaceans. International Whaling Commission (special issue 15), Cambrige.

Cremer, M.J., Brutto, L.F., Simões-Lopes, P.C. and Diefenbach, C.O. (1995) The incidental catch of Pontoporia blainvillei in Santa Catarina state, southern Brazil. Page 26 in Abstracts, XI Biennial Conference on the Biology of Marine Mammals, 14 -18 December, Orlando.

Crespo, E.A., Perez-Macri, G. and Praderi, R. (1986) Estado atual de la población de franciscana (Pontoporia blainvillei) en las costas uruguayas. Pages 92-105 in Castello, H.P. (Ed.) Actas I Reunión de Trabajo de Especialistas en Mamíferos Acuáticos de América del Sur, Buenos Aires.

Crespo, E.A., Corcuera, J.F. and Cazorla, A.L. (1994) Interactions between marine mammals and fisheries in some coastal fishing areas of Argentina. Pages 269-282 in Perrin, W.F, Donovan, G.P. and Barlow, J. (Eds) Gillnets and cetaceans. International Whaling Commission (special issue 15), Cambrige.

Danilewicz, D.S., Secchi, E.R., Ott, P.H. and Moreno, I.B. (2000) Analyses of the age at sexual maturity and reproductive rates of franciscanas (Pontoporia blainvillei) from Rio Grande do Sul, Southern Brazil. Comunicações do Museu de Ciências e Tecnologia PUCRS, Série Zoologia, 13(1): 89-98.
Di Beneditto, A.P.M., Ramos, R.M.A. and Lima, N.R.W. (1998) Fishing activity in northern Rio de Janeiro State (Brazil) and its relation with small cetaceans. Brazilian Archives of Biology and Technology 41(3): 296-302.

Di Beneditto, A.P.M. and Ramos, R.M.A. (2000) Pontoporia blainvillei (Gervais \& D'Orbigny, 1844) in the northern Rio de Janeiro $\left(21^{\circ} 18^{\prime} \mathrm{S}-22^{\circ} 25^{\prime} \mathrm{S}\right)$, Brazil. Technical Paper WP11 presented to the IV Workshop para a Coordenação da Pesquisa e Conservação da Franciscana,Pontoporia blainvillei, no Atlântico Sul Ocidental. 0509 November, Porto Alegre.

Haimovici, M., Castello, J.P. and Vooren, C.M. (1997) Fisheries. Pages 184-96 in Seeliger, U.,Odebrecht, C. and Castello, J.P. (Eds) Subtropical Convergence Environments - the coasts and sea in the southwestern Atlantic. Springer-Verlag: Berlin, Heidelberg, New York.

Kasuya, T. and Brownell, R.L. (1979) Age determination, reproduction and growth of franciscana dolphin, Pontoporia blainvillei. Scientific Reports of the Whales Research Institute 31: 45-67.

Kinas, P.G. (2000) The impact of incidental kills by gillnets on the franciscana dolphin (Pontoporia blainvillei) in southern Brazil. Technical Paper WP1 presented to the IV Workshop para a Coordenação da Pesquisa e Conservação da Franciscana, Pontoporia blainvillei, no Atlântico Sul Ocidental.05-09 November, Porto Alegre.

Kinas, P.G. and Secchi, E.R. (1998) Modelling truncated data to estimate incidental kills of franciscana, Pontoporia blainvillei, by gillnets. Reports of the International Whaling Commission 48: 533-536.

Kinas, P.G. and Secchi, E.R. (1999) Modelling truncated data to estimate incidental kills of franciscana, Pontoporia blainvillei, by gillnets. Page 51 in Abstracts, ICES/SCOR Symposium on Ecosystem Effects of Fishing. 16-19 March. Montpellier.

Lodi, L. and Capistrano, L. (1990) Capturas acidentais de pequenos cetáceos no litoral norte do Rio de Janeiro. Biotemas 3: 47-65.

Moreno, I.B., Danilewicz, D., Ott, P.H., Martins, M.B., Oliveira, L.R. and Caon, G. (2001) 10 anos de praia: Uma revisão dos registros de mamíferos marinhos no litoral norte do Rio Grande do Sul, Brasil, entre 1991-2001. Page 44 in Abstracts, I Congresso Brasileiro de Mastozoologia, 06-09 September, Porto Alegre.

Moreno, I.B., Ott, P.H. and Danilewicz, D.S. (1997) Análise preliminar do impacto da pesca artesanal costeira sobre Pontoporia blainvillei no litoral norte do Rio Grande do Sul, sul do Brasil. Pages 31-41 in Pinedo, M.C. and Barreto, A.S. (Eds) Anais do $2^{\circ}$ Encontro sobre a Coordenação de Pesquisa e Manejamento da Franciscana. Ed. FURG, Rio Grande.

Ott, P.H. (1998) Análise das capturas acidentais de Pontoporia blainvillei (Gervais \& D'Orbigny, 1844) (Cetacea, Pontoporiidae) nas comunidades pesqueiras do litoral Norte do Rio Grande do Sul, Sul do Brasil. Master Thesis. Pontifícia Universidade Católica do Rio Grande do Sul, Porto Alegre. 121pp.

Ott, P.H., Moreno, I.B. and Danilewicz, D.S. (2000a) Estimativa da mortalidade anual de Pontoporia blainvillei nas comunidades pesqueiras do litoral norte do Rio Grande do Sul, Sul do Brasil. Pages 65-67 in UNEP/CMS (Eds) Report of the Third Workshop for Coordinated Research and Conservation of the Franciscana Dolphin (Pontoporia blainvillei) in the Southwestern Atlantic. UNEP/CMS, Bonn.

Ott, P.H., Secchi, E.R., Crespo, E.A. and Dans, S. (2000b) Estrutura etária da população de Pontoporia blainvillei acidentalmente capturada pela atividade pesqueira na costa do Rio Grande do Sul - Brasil. Pages 62-64 in UNEP/CMS (Eds) Report of the Third Workshop for Coordinated Research and Conservation of the Franciscana Dolphin (Pontoporia blainvillei) in the Soutwestern Atlantic. UNEP/CMS, Bonn.

Perez-Macri, G. and Crespo, E.A. (1989) Survey of the franciscana, Pontoporia blainvillei, along the Argentine coast, with a preliminary evaluation of mortality in coastal fisheries. Pages 57-63 in Perrin, W.F., Brownell, R.L., Kaiya, Z. and Jiankang, L. (Eds) Biology and Conservation of the River Dolphins. Occas. pap. IUCN SSC 3. Gland. 
Pilleri, G. (1971) On the La Plata dolphin Pontoporia blainvillei off the Uruguayan coast. Investigation on Cetacea 3: 69-73.

Pinedo, M.C. (1982) Análise dos conteúdos estomacais de Pontoporia blainvillei (Gervais \& D'Orbigny, 1844) e Tursiops gephyreus (Lahille, 1908) (Cetacea, Platanistidae e Delphinidae) na zona estuarial e costeira de Rio Grande, R.S., Brasil. Master Thesis. Fundação Universidade do Rio Grande. Rio Grande. 95pp.

Pinedo, M.C. (1986) Mortalidade de Pontoporia blainvillei, Tursiops gephyreus, Otaria flavescens e Arctocephalus australis na costa do Rio Grande do Sul, Brasil, 1976-1983. Pages 187-199 in Castello, H.P. (Ed.) Actas I Reunión de Trabajo de Especialistas en Mamíferos Acuáticos de América del Sur, Buenos Aires.

Pinedo, M.C. (1994a) Review of small cetacean fishery interactions in southern Brazil with special reference to the franciscana, Pontoporia blainvillei. Pages 251-259 in Perrin, W.F, Donovan, G.P. and Barlow, J. (Eds) Gillnets and cetaceans. International Whaling Commission (special issue 15), Cambrige.

Pinedo, M.C. (1994b) Impact of incidental fishery mortality on the age structure of Pontoporia blainvillei in southern Brazil and Uruguay. Pages 261-264 in Perrin, W.F, Donovan, G.P. and Barlow, J. (Eds) Gillnets and Cetaceans. International Whaling Commission (special issue 15), Cambridge.

Popovici, Z. and Angelescu, V. (1954) La Economía del Mar. Instituto de Investigación en Ciencias Naturales y Museo Argentino de Ciencias Naturales "Bernardino Rivadavia". Buenos Aires, 1056pp.

Praderi, R, (1984) Mortalidad de franciscana, Pontoporia blainvillei, en pesquerías artesanales de tiburón en la costa atlántica uruguaya. Actas III Reunión Iberoamericana de Conservación y Zoología de Vertebrados. Revista del Museo Argentino de Ciencias Naturales "Bernardino Rivadavia", Zoología XIII (1-60): 259-272.

Praderi, R. (1985) Relacciones entre Pontoporia blainvillei (Mammalia: Cetacea) y tiburones (Selachii) de aguas Uruguyas. Comunicados Zoologicos del Museu História Natural de Montevideo 11(151): 1-9.

Praderi, R. (1997) Análisis comparativo de estadísticas de captura y mortalidad incidental de Pontoporia blainvillei em Uruguay durante 20 años. Pages 42-53 in M.C. Pinedo, and Barreto A.S. (Eds) Anais do $2^{\circ}$ Encontro sobre Coordenação de Pesquisa e Manejo da Franciscana. Ed. FURG, Rio Grande.

Praderi, R., Pinedo, M.C. and Crespo, E.A. (1989) Conservation and management of Pontoporia blainvillei in Uruguay, Brazil and Argentina. Pages 52-56 in Perrin, W.F., Brownell, R.L., Kaiya, Z. and Jiankang, L. (Eds) Biology and Conservation of the River Dolphins. Occas. pap. IUCN SSC 3. Gland.

Ramos, R.M.A., Di Beneditto, A.P.M. and Fernandes, L.C.C. (1994) Relatório, Plano de Conservação e Manejo de Pequenos Cetáceos - Projeto Cetáceos. Fundação Brasileira para a Conservação da Natureza (unpublished). 3pp.

Ramos, R.M.A, Di Beneditto, A.P.M. and Lima, N.R.W. (2000) Growth parameters of Pontoporia blainvillei and Sotalia fluviatilis (Cetacea) in northern Rio de Janeiro, Brazil. Aquatic Mammals 26: 65-75.

Rosas, F.W., Monteiro Filho, E.L.A. and Oliveira, M.R. (2000a) Incidental catches of franciscana dolphins (Pontoporia blainvillei) on the southern coast of São Paulo State and the coast of Paraná State, Brazil. Technical Paper WP2 presented to the IV Workshop para a Coordenação da Pesquisa e Conservação da Franciscana, Pontoporia blainvillei, no Atlântico Sul Ocidental. 05-09 November. Porto Alegre.

Rosas, F.W., Zanelatto, R.C. and Oliveira, M.R. (2000b) Mortalidade de Pontoporia blainvillei no litoral do Paraná, Brasil. Período 19911997. Pages 68-70 in UNEP/CMS (Eds) Report of the Third Workshop for Coordinated Research and Conservation of the Franciscana Dolphin (Pontoporia blainvillei) in the Southwestern Atlantic. UNEP/CMS, Bonn.

Schmiegelow, J.M.M. (1990) Estudo sobre cetáceos odontocetes encontrados em praias da região entre Iguape (SP) e Baía de Paranaguá (PR) $\left(24^{\circ} 42^{\prime} S-25^{\circ} 28^{\prime} S\right)$ com especial referência a Sotalia fluviatilis (Gervais, 1853) (Delphinidae). Master Thesis, Universidade de São Paulo, São Paulo. 149pp.

Secchi, E.R. (1999) Taxa de crescimento potencial intrínseco de um estoque de franciscanas, Pontoporia blainvillei (Gervais \& D'Orbigny, 1844) (Cetacea, Pontoporiidae) sob o impacto da pesca costeira de emalhe. Master Thesis. Fundação Universidade Federal do Rio Grande, Rio Grande. 152pp.

Secchi, E.R., Danilewicz, D. and Ott, P.H. (in press) Applying the phylogeographic concept to identify franciscana dolphin stocks: implications to meet management objectives. Journal of Cetacean Research and Management.

Secchi, E.R., Ott, P.H. and Danilewicz, D. (2002) Report of the fourth workshop for the coordinated research and conservation of the franciscana dolphin (Pontoporia blainvillei) in the western South Atlantic. The Latin American Journal of Aquatic Mammals (special issue) 1: 11-20.

Secchi, E.R., Zerbini, A.N., Bassoi, M., Dalla Rosa, L., Moller, L.M. and Roccha-Campos, C.C. (1997) Mortality of franciscanas, Pontoporia blainvillei, in coastal gillneting in southern Brazil: 1994-1995. Reports of the International Whaling Commission 47: 653-658.

Secchi, E.R. and Ott, P.H. (2000) A profundidade como um fator determinante da distribuição de toninhas, Pontoporia blainvillei, conforme indicado pelos índices de CPUE. Pages 55-57 in UNEP/ CMS (Eds) Report of the Third Workshop for Coordinated Research and Conservation of the Franciscana Dolphin (Pontoporia blainvillei) in the Soutwestern Atlantic. UNEP/CMS, Bonn.

Secchi, E. and Kinas, P.G. (2000) Evidências para o declínio de um estoque de franciscanas, Pontoporia blainvillei, devido às capturas acidentais em redes de emalhe. Technical Paper WP13 presented to the IV Workshop para a Coordenação da Pesquisa e Conservação da Franciscana, Pontoporia blainvillei, no Atlântico Sul Ocidental. 05-09 November. Porto Alegre.

Secchi, E.R., Slooten, E. and Fletcher, D. (2000) Population Viability Analysis (PVA) for a franciscana stock: when is time for action? Technical Paper WP6 presented to the IV Workshop para a Coordenação da Pesquisa e Conservação da Franciscana, Pontoporia blainvillei, no Atlântico Sul Ocidental. 05-09 November. Porto Alegre.

Secchi, E.R., Ott, P.H., Crespo, E.A., Kinas, P.G., Pedraza, S.N. and Bordino, P. (2001) A first estimate of franciscana (Pontoporia blainvillei) abundance off southern Brazil. Journal of Cetacean Research and Management 3: 95-100.

Siciliano, S. (1994) Review of small cetacean and fishery interactions in coastal waters of Brazil. Pages 241-250 in Perrin, W.F., Donovan, G.P. and Barlow, J. (Eds) Gillnets and cetaceans. International Whaling Commission (special issue 15), Cambridge.

UNEP/CMS (2000) Report of the Third Workshop for the Coordinated Research and Conservation of the Franciscana Dolphin (Pontoporia blainvillei) in the Southwestern Atlantic. UNEP/CMS Secretariat, Bonn.

Van Erp, I. (1969) In quest of the La Plata dolphin. Pacific Discovery 22: $18-24$.

Vicente, A.F.C., Santos, M.C.O., Zampirolli, E., Alvarenga, F.S. and Souza, S.P. (2000) Franciscana, Pontoporia blainvillei, in the coast of São Paulo State, Brazil. Technical Paper WP19 presented to the IV Workshop para a Coordenação da Pesquisa e Conservação da Franciscana, Pontoporia blainvillei, no Atlântico Sul Ocidental. 0509 November. Porto Alegre.

Zanelatto, R.C. (1997) Captura acidental de toninha, Pontoporia blainvillei, (Gervais \& D'Orbigni, 1844) (Cetacea, Pontoporiidae) no litoral do estado do Paraná, Brasil. Pages 22-29 in Pinedo, M.C. and Barreto, A.S. (Eds) Anais do $2^{\circ}$ Encontro sobre Coordenação de Pesquisa e Manejo da Franciscana. Ed. FURG, Rio Grande. 